\title{
Influence of Yoga Program in Low Back Pain
}

\author{
Paulo Roberto Veiga Quemelo* and Fabrício Mucin Miguel \\ Department of Physiotherapy, Sao Camilo University Center, Brazil
}

Submission: February 22, 2018; Published: March 14, 2018

*Corresponding author: Paulo Roberto Veiga Quemelo, Department of Physiotherapy, Sao Camilo University Center, Sao Paulo, Brazil, Email: pquemelo@hotmail.com

\begin{abstract}
Lower back pain is a frequent health problem caused by changes in spinal muscles, bones, discs or nerves. Different intervention modalities are used for the treatment of low back pain; including the use of medications, exercises, surgery and the empowerment of patients for selfmanagement of the problem. Yoga is an exercise form that involves the body and mind sometimes used for non-specific low back pain. Yoga presented low to moderate scientific evidence as a form of treatment of low back pain. Future studies with a larger number of participants and more precise methodology are necessary.
\end{abstract}

\section{Introduction}

Low back pain is an extremely common musculoskeletal disorder in general population. According to World Health Organization, it affects $80 \%$ to $90 \%$ of persons at some point in lifetime. In most cases low back pain is non-specific cause and resolve spontaneously. Low back pain may be subdivided into: acute (less than four weeks), subacute (four to twelve weeks) and chronic (more than twelve weeks months) episodes. Chronic conditions affect about $20 \%$ of the adult population and can lead to complications such as functional disability, depression, sleep disturbances, withdrawal from work and reduction of patients' quality of life. Although the cause of the problem is still widely discussed, there is a consensus in the literature about various factors (genetic, age, overweight, working conditions, etc.) associated with low back pain crises. Thus, most low back pain is of multifactorial origin and need a multifactorial approach [1,2].

The treatment of low back pain varies according to the duration of symptoms, the potential cause (fracture, discopathy, spondylolisthesis, myofascial syndrome), the presence or absence of radiculopathy and the results of imaging exams. Treatment of an acute episode of back pain includes relative rest, activity modification, nonsteroidal anti-inflammatories, empowerment of the population and physical therapy. However, some patients do not have a good outcome and end up to chronic conditions $(20 \%)$; part of this cases the surgical approach is necessary to reduce the pain and improve the patient's function. Although the recent articles point to the need for more studies with better methodological design and with long-term follow-up; it is a consensus that adequate and well-directed physical exercise prevents low back pain, at least in the short time. According with National Institute for Health and Care Excellence Guideline, physical exercise and manual therapy is the first front line for the treatment to low back pain or sciatic nerve inflammation in patients over 16 years of age. The main exercises used are: muscle strengthening, stretching, postural control and aerobic exercises $[3,4]$. Yoga is a kind of exercise that involves the body and mind sometimes used for non-specific low back pain. Yoga is considered as a good non-pharmacological intervention and complementary to therapy. This exercise appeared in ancient India many years ago which has also become popular in the West country over the last decades. There are different styles of yoga class, with varying philosophies and practices; most yoga exercises involve the integration of controlled breathing, physical poses and meditation [5]. According to Taneja [6], Yoga is the union of the individual consciousness with the supreme consciousness and involves eight steps. An analytical look at the eight steps and the goal of Yoga shows a holistic way of life that results in a state of complete physical, social, mental, spiritual, and in harmony with nature. Yoga exercises have been used to manage the health problems of the population, improving physical, mental and behavioral conditions. Theoretically, Yoga can improve the strength, flexibility, corporal conscience, motor coordination and mental aspects; these changes bring stabilization and muscular balance to the abdominal region and spine, which can protect and prevents new low back pain episodes $[7,8]$. However, recent systematic review showed that the evidence is low to moderate in low back pain treatments [9]. Additionally, studies have been used short periods of meditation for therapeutic purposes, which can generate bias and misinterpretations about the results on this therapy. 
Anyway, during the Yoga treatment (rehabilitation process) the participation and adherence of the patient is essential to achieve better results with the management of low back pain [10]. Thus, empowerment and educational actions can be the key to greater adherence in Yoga programs with better results.

\section{Conclusion}

Yoga is an exercise modality with low cost and that not associated with serious adverse events. Although some studies of low and moderate quality show benefits of applying Yoga in patient with low back pain; additional high-quality research with long-term of the follow-up are required to improve confidence in estimates of effect of Yoga intervention.

\section{References}

1. Qaseem A, Wilt TJ, McLean RM, Forciea MA, Clinical Guidelines Committee of the American College of Physicians (2017) Noninvasive treatments for acute, subacute, and chronic low back pain: a clinical practice guideline from the American college of physicians. Ann Intern Med 166(7): 514-530.

2. Patrick N, Emanski E, Knaub MA (2014) Acute and chronic low back pain. MedClin North Am 98(4): 777-789.

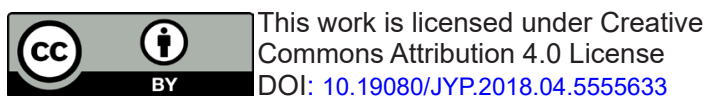

3. Wong JJ, Côté P, Sutton DA, Randhawa K, Yu H, et al. (2017) Clinical practice guidelines for the noninvasive management of low back pain: A systematic review by the Ontario Protocol for Traffic Injury Management (OPTIMa) Collaboration. Eur J Pain. 21(2): 201-216.

4. National Institute of Health and Care Excellence (2014) NICE Guidance.

5. Hayes M, Chase S (2010) Prescribing yoga. Primary Care: Clinics in Office Practice 37(1): 31-47.

6. Taneja DK (2014) Yoga and health. Indian J Community Med 39(2): 6872.

7. Daubenmier J, Mehling W, Price C, Bartmess Levasseur E, Acree M, et al. (2012) Exploration of body awareness and pain and emotion regulation among yoga and meditation practitioners: does type of mind-body practice matter? BMC Complementary \& Alternative Medicine 12(Suppl 1): 054.

8. Goode AP, Coeytaux RR, McDuffie J, Duan Porter W, Sharma P, et al. (2016) An evidence map of yoga for low back pain. Complement Ther Med 25: 170-177.

9. Wieland LS, Skoetz N, Pilkington K, Vempati R, D'Adamo CR, et al (2017) Yoga treatment for chronic non-specific lowback pain. Cochrane Database Syst Rev 1: CD010671.

10. Brämberg EB, Bergström G, Jensen I, Hagberg J, Kwak L (2017) Effects of yoga, strength training and advice on back pain: a randomized controlled trial. MC Musculoskelet Disord 18(1): 132.

\section{Your next submission with Juniper Publishers will reach you the below assets}

- Quality Editorial service

- Swift Peer Review

- Reprints availability

- E-prints Service

- Manuscript Podcast for convenient understanding

- Global attainment for your research

- Manuscript accessibility in different formats

( Pdf, E-pub, Full Text, Audio)

- Unceasing customer service

Track the below URL for one-step submission https://juniperpublishers.com/online-submission.php 